
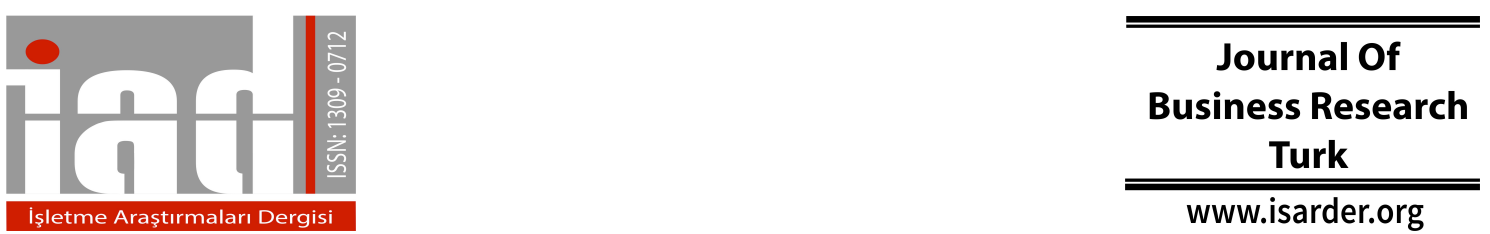

\title{
Developing Competitive Strategies Based on SWOT Analysis in Porter's Five Forces Model by DANP
}

\author{
Melahat ÖNEREN \\ Kırıkkale University \\ Business Department, \\ Kirikkale, Turkey \\ melahatoneren@mynet.com
}

\author{
Tayfun ARAR \\ Kırıkkale University \\ Business Department \\ Kirikkale, Turkey \\ tayfunarar@,kku.edu.tr
}

\author{
Gülşen YURDAKUL \\ Kırıkkale University \\ Business Department \\ Kirikkale, Turkey \\ gulsen.yurdakul10@gmail.com
}

\begin{abstract}
In such a competitive business area, companies which are especially pioneers in the sector try to develop sustainable and competitive strategies to retain their positions in the market. In this purpose, in literature many theories have been developed. Because each of those strategies have their own strong and weak sides, developing new strategical analyses keeps on. In this research an integrated model of SWOT (StrengthsWeakness-Opportunities-Threats) Analysis and Porter's Five Forces Model has been used to develop a competitive strategy model for a business firm in food sector by DEMATEL (Decision Making Trial and Evaluation Laboratory) and ANP (Analytic Network Process) techniques. Based on results, in regards of relative important items those are related to strengths and opportunities in competitors force which have considerable weights in the global weights table, maxi-maxi type competitive strategies have been developed for the company.
\end{abstract}

Keywords: SWOT Analysis, Porter's Five Forces Model, DEMATEL, ANP, Competitive Strategy

\section{Introduction}

In many business areas, food sector is one of the inevitable field and can be defined as both a need and a luxury. Depending on the target market, competitiveness of the industry changes in type of food. Since its discovery, cacao is one of the most preferred taste among consumers. Companies related with chocolate use this raw material (cacao) in many ways to catch the loyalty of their customers. Despite the existence of different qualities in the market, scientist claim that especially dark chocolate products increase happiness (mentalhealthdaily.com, 2015), regardless of the socio-economic level. That is why, products containing chocolate are irrevocable for all age gap groups of people. Food sector itself has a considerable importance in Turkey's market with a $19 \%$ of gross domestic products' share according to an annual report of food and beverage industry associations as 22000 different sized companies at all (TUGIS, 2016, p. 2). In this competitive and non-bounded business area, those companies need to develop strategies to survive. But as many failures in the market indicate that some strategies determined may not be that well-structured, adaptable to dynamic environment or non-durable to time (Lee and Ko, 2000, p. 68). Thus whilst 
developing a strategy, they shall use some strategic analysis techniques for the first step of a successful strategic management process. In this strategic analysis process, first; internal situation of the organization should be concerned and then the external environment at micro and macro levels to be examined (Güçlü, 2003, p. 78) to reduce uncertainty and possible risks (Sheykan et al., 2014, p. 313). There are pretty methods with pros and cons to analyze organizations in the frame of strategic management. Among those, one of the most used method is SWOT analysis. By the aim of using as to determine a strategy resulting an effective link between the internal and external factors (Kajanus et al., 2012, p. 1) of SWOT analysis which is the abbreviation form of the letters; $\mathrm{S}$ for strengths, $\mathrm{W}$ for weakness, $\mathrm{O}$ for opportunity and $\mathrm{T}$ for threats. This method, proposed by Welhrich first, is a strategy development technique concerning competitive situation (Xingang et al., 2013, p. 605) and can be a good point to start strategic planning process. In SWOT analysis, companies analyze internal dynamics of the organization while examining the external environment to take position for possible incomings. In literature, SWOT analysis is used in many researches for analyzing mostly business companies or sectors. The reason of this high using ratio may be its nature for analyzing the unit at such basic level regarding of rationality. However there are some criticisms for this method as being unsystematic, lack of quantification and estimating feature, and depending on subjectivism (Agarwal et al., 2012, p. 12). SWOT analysis may also result in misleading outcomes when used alone because of its lack of obvious justification, so it should be integrated with other strategic analysis tools to give more corrected results in deeper strategic insights (Ip and Koo, 2004, p. 534). For this reason another method used as integration with SWOT analysis in this research is Porter's Five Forces Model. Despite the ratio of using this method is not as popular as SWOT, this technique is used in many researches in the literature in strategic analysis process, too (Grundy, 2006, p. 214). Porter's Five Forces Model which was proposed by Michael Porter in late of 1970s (Dobbs, 2014, p. 32), constitutes of powerful buyers, powerful suppliers, potential new entrants, substitute products and competitive rivalry (Porter, 1979, p. 141) as the determinants the competition level of the industry. In this model, each force may have different effects on the strategies that companies would develop to increase profitability and gain competitive advantage (Arons and Waalewijn, 1999, p. 3). Porter's model provides a sight to all forces those have considerable effect on strategies to be able to compete in the industry (Rajasekar et al., 2013, p. 239).

Throughout the literature, there are some studies which integrated two or three strategic analysis models. In Bernroider's (2002) study, SWOT analysis factors of different sized software companies were determined in the frame of Porter's Five Forces Model and tried to indicate the analysis differences depending on the sizes. Barboza and Rojo (2015) used SWOT, BCG matrix and Porter's Five Forces to analyze the position of the company in the market. Another study that is close to this research is made by Zhu et al. in 2014 , as analyzing the industry with integration of SWOT and PEST analysis, though new two factors have been found and added as environmental and legal named PESTEL. Naserbakht and his friends (2008) used SWOT analysis with Porter's Diamond Model to analyze Iranian technology parks' competitiveness level. These studies are all constitutively based on SWOT factors in the end. But all of those studies ignore one point. Though SWOT analysis provides a great basis for strategy developing process, it can be used better in a way that when its factors are investigated analytically in a quantitative way (Kurtilla et al., 2000, p. 42). This means that SWOT factors need to be analyzed by MCDM (Multi Criteria Decision Models) methods to be 
commensurable. Because analysis items related with each factor of SWOT does not need to have same level importance on determining the strategy. In Sheykhan and his friends' study (2014) they used SWOT and Porter's Generic Strategies those are product differentiation, cost leadership and focus strategy to develop strategies and ordered them by using PROMETHEE II method. In literature there are other studies those work SWOT factors with other MCDM technique like AHP - Analytic Hierarchy Process (Shrestha et al., 2004; Kahraman et al., 2007; Arslan and Turan, 2009; Görener et al., 2012). But there is also another point in those studies that is ignored. Applying such an analysis as SWOT, it would not be so theoretical and practical considering the components of the analysis shall be independent from each other. How can it be prejudged before analyzing that opportunities of an organization or an industry would be independent from its strengths? There are studies in the literature those had overcome this issue by analyzing SWOT factors with ANP (Analytic Network Process) by considering the dependencies among the factors such as Yüksel and Dağdeviren (2007) and Catron et al. (2013). In those studies authors presumed the dependencies either judgmental or due to expert's views without using specific techniques as DEMATEL to determine possible dependencies. In this research, first by proposed model, insufficient sides of the studies mentioned above are fulfilled. Then according to results, competitive strategies will be suggested in the discussion part.

\section{Methodology and Application}

In this research, SWOT Analysis of a firm in food sector has been made based on Porter's Five Forces Model. This firm started up business in chocolate cream sector in Italy, 1942; is still an international and pioneer company in its area as known worldwide firm. The company started running business in Turkey a quarter-century ago and began producing its products in this year.

In order to do the purposed analysis and develop strategies for firm, DEMATEL and ANP techniques are used. In this direction, first main and sub criteria have been determined. While main criteria constitute Porter's Five Forces; sub criteria are the components of SWOT Analysis in the coverage of each force of Porter. In the application process, face to face and online interviews with managers of manufacturing, human resources, marketing, exporting and importing departments of the company in Turkish market have been made. In the questionnaire form delivered to those managers; there are two matrices. First is the direct correlation matrix of Porter's five forces as having the importance of how related to each other in developing a strategy. Arithmetic means of the answers gathered from the managers have been considered and analyzed in DEMATEL technique. Second type matrices are pairwise comparison of SWOT components. Geometric means of the answers gathered from the managers have been considered and analyzed in ANP technique. At last, all main and sub criteria were ordered in case of their importance weights and competitive strategies have been developed due to the relative important ones.

The main purpose is, according to the results of DEMATEL and ANP, to develop competitive strategies to the firm. In regard of being more rational, the strategies have been developed not only in case of SWOT analysis, but also to be more comprehensive, closer external environment of the firm has been considered by Porter's model. This extensive model is due to evaluating each component of SWOT in regard of Porter's model and determined as seen in Figure 1. All computes are made by Microsoft Excel 2016. 
M. Öneren - T. Arar - G. Yurdakul 9/2 (2017) 511-528

- Brand Loyalty in Market (NES1)

- Brand Reputation (NES2)

- High Level of Capital Requirements (NES3)

- Qualified Workforce (NES4)

- Lower Priced Products (NEW)

- Offers \& Promotion (NEO)

- Threats for Market Share of the Business Firm (NET1)

- Possible Cheap Copy Made (NET2)

- Existence of Alternative Suppliers for Same Producut (SPS

- Scarce of Raw Material/Suppliers (SPW)

- Backward Integration and Power of Firm to Buy Suppliers (SPO)

- Rising of Raw-Material Prices (SPT1)

- Descending Quality of Raw-Material (SPT2)

Suppliers

- Forward Integration (SPT3)

(SP)

- Brand Loyalty (BS2)

- High Prices (BW1)

- Increasing Demand for Products in Special Days; Valentines, Christmas etc. (BO)

Buyers (B)

- Healthy Nutrition Orientation (BT)

- Brand Value (SBS)

- Value Loss of Turkish Liras to $\$$ and Rising Production Costs (SBW)

- Product Differentiation (SBO)

Substitute

- Product or Brand Boycotts (SBT)

(SB)

- Expert in Field (CS1)

- Brand Position in International Area (CS2)

- High, Fix and Variable Costs' Impact on Prices (CW)

Competitors $\begin{aligned} & \text { - Successful Partnerships (CO) } \\ & \text { - Impact of Competitevess on Costs (CW) }\end{aligned}$

Competitors $\quad \begin{aligned} & \cdot \text { Successful Partnerships }(\mathrm{CO}) \\ & \cdot \text { Impact of Competitevess on Costs (CW) }\end{aligned}$

(C) 


\section{DEMATEL}

DEMATEL technique which is the abbreviation form of "Decision Making Trial and Evaluation Laboratory" was developed by Science and Human Affairs Program of the Battelle Memorial Institute of Geneva between years 1972 and 1979 (Liu, 2016, p. 383). This technique leads other MCDM (Multi-Criteria Decision Models) and used to comprehend the possible causal relation among the factors and split them into cause and result groups (Aksakal and Dağdeviren, 2010, p. 907). The five steps of this technique are as follows (Supeekit et al., 2016, p. 323):

\section{Step 1: Calculating Direct Relation Matrix}

In this step, opinions of managers have been gathered and to build the average direct relation matrix (AD) for Porter's five forces as main criteria based on the DEMATEL Scale in Table 1.

Table 1. DEMATEL Scale

\begin{tabular}{cc}
\hline Numerical Expression & Definition \\
\hline 0 & No Impact \\
1 & Low Impact \\
2 & Medium Impact \\
3 & High Impact \\
4 & Very High Impact \\
\hline
\end{tabular}

$A D=\quad \begin{array}{ccc}a_{11} & a_{i j} & a_{1 \pi} \\ a_{n} & a_{i j} & a_{i n} \\ a_{121} & a_{n j} & a_{n \pi}\end{array}$

Step 2: Calculating Normalized Direct Relation Matrix

In this step, direct relation matrix is normalized as using equation 2 and 3.

$N D=m \cdot A D$

where $\mathrm{m}=\max \left(\max \left(\sum_{i=1}^{i !} a_{i i}\right), \max \left(\sum_{i=1}^{i !} a_{i i}\right)\right)$

Step 3: Calculating Total Relation Matrix

In this step, total relation matrix (TR) is built via equation 4.

$\boldsymbol{T} \boldsymbol{R}=\mathrm{ND}(\mathrm{l}-\mathrm{ND})^{-1}$

where I is identity matrix.

Step 4: Calculating Sender and Receiver Group

In this step, sums of rows and columns of total relation matrix are calculated. The vector $\mathrm{R}$ and $\mathrm{C}$ can be found as follows:

$\boldsymbol{R}=\quad R_{\mathrm{j}_{\mathrm{n} 1}}=\sum_{i=1}^{i !} T R_{i j_{n \times 1}}$ where $R_{\mathrm{j}}$ is the total effects (sender group)

$C=\quad \mathrm{C}_{\mathrm{i} \times 1}=\sum_{i=1}^{i !} T R_{i j_{n \times 1}}$ where $\mathrm{C}_{\mathrm{i}}$ is the influenced ones (receiver group)

Step 5: Setting the Threshold Value and Obtaining Impact Diagraph Map 
In this step, a threshold value is determined. In this study this value is obtained by the mean of the total relation matrix. This value is important in obtaining the map to see the interrelationship and effects and causes among the factors.

\section{Analytic Network Process (ANP)}

Analytic Network Process (ANP) has been developed by Saaty as more general and improved form of Analytic Hierarchy Process (AHP) (Wang et al., 2015, p. 40). While in AHP technique dependencies among criteria and alternatives are ignored, only the hierarchy from top to bottom is considered; in real life problems, there may be dependencies and relations among the criteria and alternatives in decisions to be made (Wudhikarn et al., 2015, p. 3). Thus, in these kinds of situations, instead of AHP, ANP technique is preferred. In ANP there are network instead of hierarchy. In the literature, there are two methods using in ANP technique to rank the alternatives or the factors (Shahabi et al., 2014, p. 19). The first of them is well known one which comprises four main steps those are (Chung et al., 2005, p. 32-34):

1. Identifying the problem and construction of the model

2. Pairwise Comparison Matrices and Calculating the Priority Vectors

3. Supermatrix and Limit matrix formation

4. Selection of the best alternative

Instead of this first formation, the second method of ANP technique is used in this research. The reason is; in the first formation, there is a supermatrix which consists all the sub-factors inner and outer dependencies to each other. But in this research, as mentioned before, only the dependencies of the main criteria those are Porter's five forces are considered. That is why the second formation will be used. Here, proposed ANP technique's steps are as follows (Yüksel and Dağdeviren, 2007, p. 3370-3371):

Step 1: Identify the items for each of SWOT components based on Porter's model.

Here the SWOT analysis components for each of Porter's five forces are determined as in Figure 1.

Step 2: Presuming there is no dependence among Porter's five forces, determine the importance degrees (priority vectors) of main criteria regarding the AHP scale as in Table 2.

Table 2. AHP Scale

\begin{tabular}{|c|c|c|}
\hline $\begin{array}{l}\text { Numerical Expression of } \\
\text { Importance }\end{array}$ & $\begin{array}{l}\text { Description of } \\
\text { Importance }\end{array}$ & Explanation \\
\hline 1 & Equal & $\begin{array}{l}\text { If } i^{\text {th }} \text { and } \mathrm{j}^{\text {th }} \text { criterion is equally } \\
\text { important }\end{array}$ \\
\hline 3 & Moderate & $\begin{array}{l}\text { If } i^{\text {th }} \text { slightly important than } \mathrm{j}^{\text {th }} \\
\text { criterion }\end{array}$ \\
\hline 6 & Strong & $\begin{array}{l}\text { If } i^{\text {th }} \text { strongly important than } \mathrm{j}^{\text {th }} \\
\text { criterion }\end{array}$ \\
\hline 7 & Very Strong & $\begin{array}{l}\text { If } i^{\text {th }} \text { much strongly important } \\
\text { than } i^{\text {th }} \text { criterion }\end{array}$ \\
\hline 9 & Absolute Strong & $\begin{array}{c}\text { If } i^{\text {th }} \text { absolute strongly important } \\
\text { than } i^{\text {th }} \text { criterion }\end{array}$ \\
\hline $2,4,6,8$ & Intermediate Values & If the decision maker is irresolute \\
\hline
\end{tabular}


In this step, via both face to face interview and online interview, pairwise comparisons are gathered from managers of human resources, exporting, importing, production and marketing departments and obtained the geometric mean of them. Here, AHP technique is applied. The steps of AHP is as follows (Supçiller and Çapraz, 2011, p. 6-9):

Step 2.1. Create a pairwise comparison matrix of the main criteria and sub criteria respectively $(i=1,2, \ldots n ; j=1,2, . ., n)$

\begin{tabular}{ccc|}
\hline Criteria & $\mathbf{i}$ & $\mathbf{j}$ \\
$\mathbf{i}$ & 1 & $u_{i j}$ \\
$\mathbf{j}$ & $\frac{1}{u_{j i}}$ & 1 \\
\hline
\end{tabular}

\section{Figure 2. Pairwise Comparison Matrix}

Step 2.2. Find the Priority Vector (PV) of each sub and main criterion (Crawford \&Williams, 1985, p. 3):

$$
w_{1}=\frac{\prod_{j-1}^{i} u_{i j}^{1 i n}}{\sum \prod_{j-1}^{i n} u_{i j}^{1 i m}}
$$

Step 2.3. Examine the Consistency Ratio (CR) of Priority Vectors

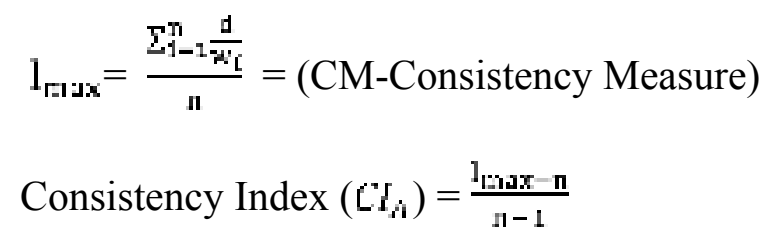

$$
\mathrm{CR}_{\mathrm{A}}=\frac{\mathrm{CI}_{\mathrm{s}}}{\mathrm{KI}_{\mathrm{a}}}
$$

Random Index*

Table 3. Random Index Values

\begin{tabular}{|c|c|c|c|c|c|c|c|c|c|}
\hline $\begin{array}{c}\text { N of } \\
\mathbf{C}\end{array}$ & 1 & 2 & 3 & 4 & 5 & 6 & 7 & 8 & 9 \\
\hline RI & 0 & 0 & 0.52 & 0.89 & 1.11 & 1.25 & 1.35 & 1.40 & 1.45 \\
\hline
\end{tabular}

Step 3: Determine the inner dependence matrix of each Porter's five force with respect to other factors

According to total relation matrix and threshold value calculated in DEMATEL technique pairwise comparison matrices are formed for the factors (Tables 8-11). Process of calculating PV, CI, RI and CRs are based on equations 8-12. In these 
comparisons the question is like; "What is the relative importance of suppliers when compared to buyers on controlling new entrants?".

\section{Step 4: Determine the interdependent priorities of Porter's five forces}

In this step two matrices are multiplied to obtain the interdependent priorities of Porter's five forces as main criteria. These matrices are $w_{2}$ calculated in Step 3 and $w_{1}$ calculated in Step 2.

Step 5: Determine the local importance degrees of SWOT components regarding the AHP Scale

In this step, pairwise comparisons of SWOT components based on each of Porter's five forces are made by the managers and geometric mean matrix of their comparisons is obtained by using the sub steps (AHP steps) of Step 2.

Step 6: Determine the global importance degrees of SWOT components based on Porter's five forces

In the last step, to find the global weights of SWOT components, matrix of SWOT components' weights regarding each Porter's five forces obtained from Step 5 is multiplied by the matrix of interdependent priorities of Porter's five forces as calculated in Step 4.

\section{Results}

Through the interviews, by data gathered by managers the results are as follows:

\section{Table 4. Final Direct Relation Matrix}

\begin{tabular}{cccccc}
\hline Direct Relation Matrix & NE & S & B & SP & C \\
\hline New Entrants & 0 & 1.6 & 2.6 & 2.8 & 2.8 \\
Suppliers & 2.8 & 0 & 1.2 & 2 & 2 \\
Buyers & 2.8 & 1.4 & 0 & 2.6 & 1.8 \\
Substitute Products & 3.6 & 2.8 & 2 & 0 & 3.6 \\
Competitors & 3.6 & 3.2 & 2.2 & 3.4 & 0 \\
\hline
\end{tabular}

Final Direct Relation Matrix is obtained by the average mean of five managers' pairwise comparison matrices of Porter's five forces' relations among each other using equation 1.

Table 5. Normalized Direct Relation Matrix

\begin{tabular}{cccccc}
\hline $\begin{array}{c}\text { Normalized Direct } \\
\text { Relation Matrix }\end{array}$ & NE & S & B & SP & C \\
\hline New Entrants & 0.000 & 0.125 & 0.203 & 0.219 & 0.219 \\
Suppliers & 0.219 & 0.000 & 0.094 & 0.156 & 0.156 \\
Buyers & 0.219 & 0.109 & 0.000 & 0.203 & 0.141 \\
Substitute Products & 0.281 & 0.219 & 0.156 & 0.000 & 0.281 \\
Competitors & 0.281 & 0.250 & 0.172 & 0.266 & 0.000 \\
\hline
\end{tabular}

Then, direct relation matrix is normalized using equations 2 and 3 in order. 
Table 6. Total Relation Matrix

\begin{tabular}{cccccc}
\hline $\begin{array}{c}\text { Total Relation } \\
\text { Matrix }\end{array}$ & NE & S & B & SP & C \\
\hline New Entrants & 0.79 & 0.71 & 0.71 & 0.87 & 0.85 \\
Suppliers & 0.84 & 0.49 & 0.54 & 0.71 & 0.69 \\
Buyers & 0.88 & 0.62 & 0.48 & 0.78 & 0.72 \\
Substitute Products & 1.16 & 0.88 & 0.77 & 0.82 & 1.01 \\
Competitors & 1.17 & 0.91 & 0.80 & 1.04 & 0.80 \\
\hline
\end{tabular}

Threshold point: 0.80 is found as the average of the matrix.

Gray cells are bigger or equal than the threshold point.

Here, total relation matrix is obtained using equation 4. Then using equations 5 and 6, impact diagraph map is obtained as follows:

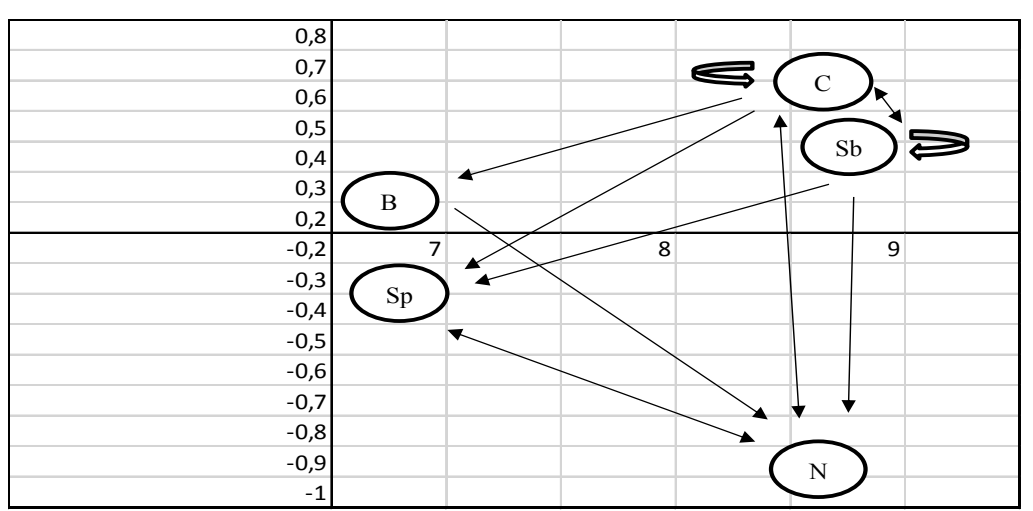

Figure 3. Impact Diagraph Map of Porter's Five Forces as Main Criteria

In Table 7, priority vectors are calculated by using equation 9. CI, RI and CR values are calculated by using equations 10,11 and 12 . This results is due to step 2 of ANP.

Table 7. Pairwise Comparison of Porter's Five Forces (Main Criteria)

\begin{tabular}{ccccccc}
\hline Pairwise Comparison & NE & S & B & SP & C & PV \\
\hline New Entrants & 1 & 0.381 & 0.184 & 0.859 & 0.296 & 0.071 \\
Suppliers & 2.627 & 1 & 0.803 & 6.119 & 1.246 & 0.278 \\
Buyers & 5.431 & 1.24573094 & 1 & 3.32269903 & 3.005 & 0.370 \\
Substitute Products & 1.165 & 0.163 & 0.301 & 1 & 0.201 & 0.065 \\
Competitors & 3.380 & 0.803 & 0.333 & 4.988 & 1 & 0.215 \\
CI & 0.058 & RI & 1.11 & CR & 0.052053 & $\leq 0.1$ \\
\hline
\end{tabular}

Thus $w_{1}=\left\|\begin{array}{l}0,071 \\ 0,278 \\ 0,370 \\ 0,065 \\ 0,215\end{array}\right\|$

From Table 8 to 11 , step 3 of ANP is applied. In Table 8, controlling new entrants, factors are pairwise compared regarding of Total Relation Matrix. Priority vectors are calculated by using equation 9 . CI, RI and CR values are calculated by using equations 10,11 and 12 . 
M. Öneren - T. Arar - G. Yurdakul 9/2 (2017) 511-528

Table 8. Pairwise Comparisons Controlling New Entrants

\begin{tabular}{cccccc}
\hline $\begin{array}{c}\text { New } \\
\text { Entrants }\end{array}$ & S & B & SP & C & PV \\
\hline Suppliers & 1.000 & 0.803 & 6.119 & 1.246 & 0.325 \\
Buyers & 1.246 & 1.000 & 3.323 & 3.005 & 0.388 \\
Substitutes & 0.163 & 0.301 & 1.000 & 0.200 & 0.065 \\
Competitors & 0.803 & 0.333 & 4.988 & 1.000 & 0.222 \\
CI & $\mathbf{0 . 0 7 2 3 2 9}$ & RI & $\mathbf{0 . 8 9}$ & $\mathbf{C R}=\mathbf{0 . 0 8 1 3}$ & $<\mathbf{0 . 1}$ \\
\hline
\end{tabular}

In Table 9, controlling suppliers, factors are pairwise compared regarding of Total Relation Matrix. Priority vectors are calculated by using equation 9. CI, RI and CR values are calculated by using equations 10,11 and 12 .

Table 9. Pairwise Comparisons Controlling Suppliers

\begin{tabular}{cccc}
\hline Suppliers & SP & C & PV \\
\hline Substitutes & 1.000 & 0.200 & 0.437 \\
Competitors & 0.333 & 1.000 & 0.563 \\
CI= 0.000 & $\mathbf{R I = 0 . 0 0 0 0 0 1}$ & $\mathbf{C R = 0}$ & $\leq \mathbf{0 . 1}$ \\
\hline
\end{tabular}

In Table 10, controlling substitutes, factors are pairwise compared regarding of Total Relation Matrix. Priority vectors are calculated by using equation 9. CI, RI and CR values are calculated by using equations 10,11 and 12 .

Table 10. Pairwise Comparisons Controlling Substitutes

\begin{tabular}{ccccc}
\hline Substitutes & NE & SP & C & PV \\
\hline New Entrants & 1.000 & 0.859 & 0.296 & 0.166 \\
Substitutes & 1.165 & 1.000 & 0.200 & 0.161 \\
Competitors & 3.380 & 4.988 & 1.000 & 0.672 \\
CR & $\mathbf{0}$ & $\mathbf{R I}=\mathbf{0 . 5 2}$ & $\mathbf{C R}=\mathbf{0}$ & $\leq \mathbf{0 . 1}$ \\
\hline
\end{tabular}

In Table 11 controlling competitors, factors are pairwise compared regarding of Total Relation Matrix. Priority vectors are calculated by using equation 9. CI, RI and CR values are calculated by using equations 10,11 and 12 .

Table 11. Pairwise Comparisons Controlling Competitors

\begin{tabular}{ccccc}
\hline Competitors & NE & S & C & PV \\
\hline New Entrants & 1.000 & 0.859 & 0.296 & 0.166 \\
Substitutes & 1.165 & 1.000 & 0.200 & 0.161 \\
Competitors & 3.380 & 4.988 & 1.000 & 0.672 \\
CR & $\mathbf{0}$ & $\mathbf{R I}=\mathbf{0 . 5 2}$ & $\mathbf{C R}=\mathbf{0}$ & $\leq \mathbf{0 . 1}$ \\
\hline
\end{tabular}

Thus $w_{2}=\left\|\begin{array}{ccccc}0 & 0 & 0 & 0,166 & 0,166 \\ 0,325 & 0 & 0 & 0 & 0 \\ 0,388 & 0 & 0 & 0 & 0 \\ 0,065 & 0,437 & 0 & 0,161 & 0,161 \\ 0,222 & 0,563 & 1 & 0,672 & 0,672\end{array}\right\|$

In Table 12 step 4 of ANP is applied and $w_{3}$ is obtained. 
M. Öneren - T. Arar - G. Yurdakul 9/2 (2017) 511-528

Table 12. Final Weights of Main Criteria

\begin{tabular}{ccccccc}
\hline \multicolumn{8}{c}{ W2 (According to Table 2 Results) } & W1 & W3 \\
\hline 0 & 0 & 0 & 0.166091 & 0.166091 & 0.071237 & 0.046617 \\
0.324934 & 0 & 0 & 0 & 0 & 0.277832 & 0.023147 \\
0.38799 & 0 & 0 & 0 & 0 & $\mathbf{x}$ & 0.370257 \\
0.065106 & 0.436793 & 0 & 0.161488 & 0.161488 & 0.065254 & 0.027639 \\
0.221971 & 0.563207 & 1 & 0.672421 & 0.672421 & 0.215419 & 0.171319 \\
\hline
\end{tabular}

Thus $w_{3}=\left\|\begin{array}{l}0,047 \\ 0,023 \\ 0,028 \\ 0,171 \\ 0,731\end{array}\right\|$

From Table 13 to 17 step 5 of ANP is applied. In Table 13 SWOT Analysis Factors for New Entrants are pairwise compared. Priority vectors are calculated by using equation 9. CI, RI and CR values are calculated by using equations 10, 11 and 12 .

Table 13. Pairwise Comparison Matrix and PVs of SWOT Analysis for New Entrants

\begin{tabular}{|c|c|c|c|c|c|c|c|c|c|}
\hline $\begin{array}{c}\text { Pairwise } \\
\text { Compariso } \\
\text { n Matrix } \\
\end{array}$ & $\begin{array}{c}\text { NES } \\
1\end{array}$ & $\begin{array}{c}\text { NES } \\
2\end{array}$ & $\begin{array}{c}\text { NES } \\
\mathbf{3}\end{array}$ & $\begin{array}{c}\text { NES } \\
\mathbf{4}\end{array}$ & $\begin{array}{c}\text { NEW } \\
1\end{array}$ & $\begin{array}{c}\text { NEO } \\
\mathbf{1}\end{array}$ & NET1 & $\begin{array}{c}\text { NET } \\
2\end{array}$ & PV \\
\hline NES1 & 1.000 & 0.582 & 0.553 & 0.339 & 2.762 & 1.780 & 0.803 & 3.743 & $\begin{array}{c}0.11 \\
7\end{array}$ \\
\hline NES2 & 1.719 & 1.000 & 1.185 & 0.725 & 3.160 & 1.451 & 1.000 & 6.119 & $\begin{array}{c}0.17 \\
5\end{array}$ \\
\hline NES3 & 1.807 & 0.844 & 1.000 & 0.844 & 1.933 & 1.380 & 2.537 & 5.165 & $\begin{array}{c}0.17 \\
7\end{array}$ \\
\hline NES4 & 2.954 & 1.380 & 1.185 & 1.000 & 2.537 & 3.005 & 1.476 & 6.119 & $\begin{array}{c}0.22 \\
7\end{array}$ \\
\hline NEW & 0.362 & 0.316 & 0.517 & 0.394 & 1.000 & 0.775 & 0.725 & 3.160 & $\begin{array}{c}0.07 \\
4\end{array}$ \\
\hline NEO & 0.562 & 0.689 & 0.725 & 0.333 & 1.290 & 1.000 & 0.491 & 1.476 & $\begin{array}{c}0.08 \\
1\end{array}$ \\
\hline NET1 & 1.246 & 1.000 & 0.394 & 0.678 & 1.380 & 2.036 & 1.000 & 1.000 & $\begin{array}{c}0.10 \\
9\end{array}$ \\
\hline NET2 & 0.267 & 0.163 & 0.194 & 0.163 & 0.316 & 0.678 & 1.000 & 1.000 & $\begin{array}{c}0.04 \\
0\end{array}$ \\
\hline CI & 0.066 & & RI & 1.4 & & CR & $\begin{array}{c}0.047 \\
4\end{array}$ & $\leq$ & 0.1 \\
\hline
\end{tabular}

In Table 14 SWOT Analysis Factors for Suppliers are pairwise compared. Priority vectors are calculated by using equation 9 . CI, RI and CR values are calculated by using equations 10, 11 and 12 . 
M. Öneren - T. Arar - G. Yurdakul 9/2 (2017) 511-528

Table 14. Pairwise Comparison Matrix and PVs of SWOT Analysis for Suppliers Pairwise

\begin{tabular}{cccccccc}
$\begin{array}{c}\text { Comparison } \\
\text { Matrix }\end{array}$ & SPS1 & SPW1 & SPO1 & SPT1 & SPT2 & SPT3 & PV \\
\hline SPS & 1.000 & 3.500 & 1.635 & 1.070 & 2.809 & 3.743 & 0.293 \\
SPW & 0.286 & 1.000 & 3.160 & 0.803 & 1.246 & 2.036 & 0.162 \\
SPO & 0.612 & 0.316 & 1.000 & 0.374 & 0.415 & 1.000 & 0.082 \\
SPT1 & 0.935 & 1.246 & 2.672 & 1.000 & 1.246 & 4.146 & 0.232 \\
SPT2 & 0.356 & 0.803 & 2.412 & 0.803 & 1.000 & 3.876 & 0.166 \\
SPT3 & 0.267 & 0.491 & 1.000 & 0.241 & 0.258 & 1.000 & 0.066 \\
CI & $\mathbf{0 . 0 6 7}$ & RI & $\mathbf{1 . 2 5}$ & $\mathbf{C R}$ & $\mathbf{0 . 0 5 4}$ & $\leq$ & $\mathbf{0 . 1}$ \\
\hline
\end{tabular}

In Table 15 SWOT Analysis Factors for Buyers are pairwise compared. Priority vectors are calculated by using equation 9 . CI, RI and CR values are calculated by using equations 10,11 and 12 .

Table 15. Pairwise Comparison Matrix and PVs of SWOT Analysis for Buyers

\begin{tabular}{ccccccc}
\hline $\begin{array}{c}\text { Pairwise } \\
\text { Comparison }\end{array}$ & BS1 & BS2 & BW1 & BO1 & BT1 & PV \\
\hline BS1 & 1.000 & 0.775 & 4.213 & 0.577 & 3.637 & 0.253 \\
BS2 & 1.291 & 1.000 & 3.637 & 1.316 & 1.592 & 0.272 \\
BW & 0.237 & 0.275 & 1.000 & 0.237 & 0.467 & 0.064 \\
BO & 1.732 & 0.760 & 4.213 & 1.000 & 2.590 & 0.294 \\
BT & 0.275 & 0.628 & 2.141 & 0.386 & 1.000 & 0.117 \\
CI & $\mathbf{0 . 0 4}$ & RI & $\mathbf{1 . 1 1}$ & $\mathbf{C R}$ & $\mathbf{0 . 0 3 6}$ & $\leq \mathbf{0 . 1}$ \\
\hline
\end{tabular}

In Table 16 SWOT Analysis Factors for Substitutes are pairwise compared. Priority vectors are calculated by using equation 9. CI, RI and CR values are calculated by using equations 10,11 and 12 .

Table 16. Pairwise Comparison Matrix and PVs of SWOT Analysis for Substitute Products

\begin{tabular}{cccccc}
\hline $\begin{array}{c}\text { Pairwise } \\
\text { Comparison }\end{array}$ & SBS & SBW & SBO & SBT & PV \\
\hline SBS & 1.000 & 1.000 & 0.250 & 0.333 & 0.119 \\
SBW & 1.000 & 1.000 & 0.903 & 0.491 & 0.180 \\
SBO & 4.004 & 1.108 & 1.000 & 0.333 & 0.244 \\
SBT & 3.005 & 2.036 & 3.005 & 1.000 & 0.458 \\
CI & $\mathbf{0 . 0 8 5}$ & RI & $\mathbf{0 . 8 9}$ & $\mathbf{C R}=\mathbf{0 . 0 9 5}$ & $<\mathbf{0 . 1}$ \\
\hline
\end{tabular}

In Table 17 SWOT Analysis Factors for Competitors are pairwise compared. Priority vectors are calculated by using equation 9. CI, RI and CR values are calculated by using equations 10,11 and 12 .

Table 17. Pairwise Comparison and PVs of SWOT Analysis for Competitors

\begin{tabular}{ccccccc}
\hline $\begin{array}{c}\text { Pairwise } \\
\text { Comparison }\end{array}$ & CS1 & CS2 & CW & CO & CT & PV \\
\hline CS1 & 1.000 & 1.000 & 3.637 & 0.760 & 2.141 & 0.246 \\
\hline
\end{tabular}


M. Öneren - T. Arar - G. Yurdakul 9/2 (2017) 511-528

\begin{tabular}{lcccccc}
\hline CS2 & 1.000 & 1.000 & 3.873 & 1.000 & 2.432 & 0.270 \\
CW & 0.275 & 0.258 & 1.000 & 0.577 & 1.316 & 0.096 \\
CO & 1.316 & 1.000 & 1.732 & 1.000 & 3.201 & 0.256 \\
CT & 0.467 & 0.411 & 0.760 & 0.312 & 1.000 & 0.093 \\
CI & $\mathbf{0 . 0 5 8}$ & $\mathbf{R I}$ & $\mathbf{1 . 1 1}$ & $\mathbf{C R}$ & $\mathbf{0 . 0 5 2}$ & $\leq \mathbf{0 . 1}$ \\
\hline
\end{tabular}

In Table 18, step 6 of ANP is applied. Weights of $w_{3}$ and the local weights calculated through tables 13 to 17 are multiplied to find the global weights.

Table 18.Global Weights

\begin{tabular}{|c|c|c|c|c|}
\hline Main Criteria & Weights & Sub Criteria & Weights & Global Weights \\
\hline \multirow{8}{*}{ New Entrants (NE) } & \multirow{8}{*}{0.047} & NES1 & 0.117 & 0.005 \\
\hline & & NES2 & 0.175 & 0.008 \\
\hline & & NES3 & 0.177 & 0.008 \\
\hline & & NES4 & 0.227 & 0.011 \\
\hline & & NEW & 0.074 & 0.003 \\
\hline & & $\mathrm{NEO}$ & 0.081 & 0.004 \\
\hline & & NET1 & 0.109 & 0.005 \\
\hline & & NET2 & 0.040 & 0.002 \\
\hline \multirow{6}{*}{ Suppliers (SP) } & \multirow{6}{*}{0.023} & SPS & 0.293 & 0.007 \\
\hline & & SPW & 0.162 & 0.004 \\
\hline & & SPO & 0.082 & 0.002 \\
\hline & & SPT1 & 0.232 & 0.005 \\
\hline & & SPT2 & 0.166 & 0.004 \\
\hline & & SPT3 & 0.066 & 0.002 \\
\hline \multirow{5}{*}{ Buyers (B) } & \multirow{5}{*}{0.028} & BS1 & 0.253 & 0.007 \\
\hline & & BS2 & 0.272 & 0.008 \\
\hline & & BW & 0.064 & 0.002 \\
\hline & & $\mathrm{BO}$ & 0.294 & 0.008 \\
\hline & & BT & 0.117 & 0.003 \\
\hline \multirow{4}{*}{ Substitute Products (SP) } & \multirow{4}{*}{0.171} & SBS & 0.119 & 0.020 \\
\hline & & SBW & 0.180 & 0.031 \\
\hline & & SBO & 0.244 & 0.042 \\
\hline & & SBT & 0.458 & 0.078 \\
\hline \multirow{5}{*}{ Competitors (C) } & \multirow{5}{*}{0.731} & CS1 & 0.246 & 0.180 \\
\hline & & CS2 & 0.270 & 0.197 \\
\hline & & $\mathrm{CW}$ & 0.096 & 0.070 \\
\hline & & $\mathrm{CO}$ & 0.256 & 0.187 \\
\hline & & CT & 0.093 & 0.068 \\
\hline
\end{tabular}

In the graph below, relative important weighted factors are determined by investigating the line's sharp fall. Thus it can be said that main factor competitors plays a considerable role in developing a strategy for the firm based on SWOT analysis integrated with Porter's five forces model. Under this force, major SWOT components are CS1, CS2 and CO those belong to Strengths and Opportunities. Thus a company should pay more attention on those items when developing a competitive strategy. In the discussion and conclusion part, we suggest competitive and sustainable strategies for the company. 


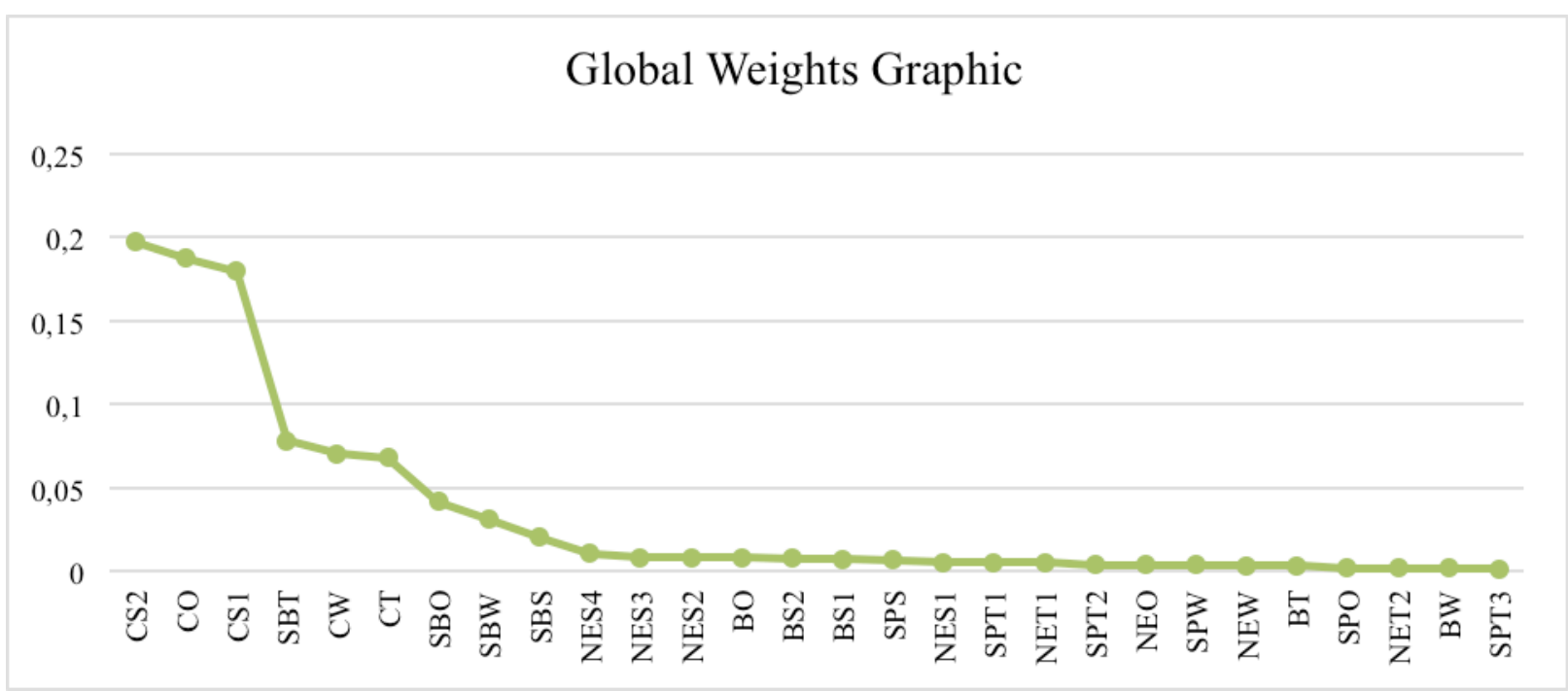

Figure 4. Importance of Sub Criteria in Graphic

\section{Discussion and Conclusion}

This study made for developing competitive strategies for a company in food sector by SWOT analysis in the frame of Porter's competitive five forces model. Results showed that, the most important three factors for the company are being expert in its field and brand position in international area as strengths and as successful partnerships as an opportunity in "competitors" segment. In these situations, company should chose $\mathrm{S} / \mathrm{O}$ combination by utilizing its strengths to maximize its opportunities. The strategies should be suggested in this frame.

Based on the results, what company should do is focusing on the idea "think global, act local" which was derived from a conference in 1979 called by same phrase (Ralph, 2006). Thus, to execute the standards that the firm strives to keep and improve in global market, it needs to adapt its steps due to the current country's market conditions. This could be practiced for firm by using its strengths to maximize the opportunities. The company may choose product differentiation which is one of Porter's generic strategies (Sheykhan et al., 2014, p. 313) of those products existing already in market by analyzing the traditions while focusing on local agricultural richness and considering the social and cultural tastes and preferences of the local it runs business in. Whilst doing all of these, strategic partnerships with the experts of products they aim to diversify with would be the second act of the strategy. Examples for diversifications by using traditional tastes of Turkey those are delight, dry fruits (almond, pistachio, peanut etc.), chestnut, baklava and citrus that is popular in Mediterranean region with chocolate. With those examples, associating with business partners (best coffee or baklava manufacturing companies in Turkey) by preserving both of its legal and economic independences would play a significant role in increasing market share in the country.

While diversifying chocolate, there is one more issue that the firm should consider. Although chocolate is such popular and preferred by people, it is a truth that some parties cannot eat or are in hesitation with eating it because of health problems mostly. If the company chose diversifying its products by using its strong sides, it would draw away its competitors. For example, the perception of most chocolate- 
products have additives and inorganic ingredients keeps customers who are either athletes and people on a diet due to the calories or diabetics and cancers due to sugar's negative effects far from this taste. In fact, this strategy could be claimed considerable on both responding to customers' wishes and launching a new area for the company itself. Alternatives such as products with lower sugar and more cacao or nut ratio may be considered.

Another strategy may be opening corner stands or stores. This would provide advantages such as accessibility, easy advertising and a wide network.

For all those strategies developed for the company to actualize requires benefitcost analyze first. The company would determine a location in the market by the results of feasibility studies in the light of the strategies developed.

This study is made for a nutrition manufacturer firm. Thus the relative importance SWOT factors may change in other companies and in other sectors (Lee and Ko, 2000, p. 68), so in the frame of contingency approach, it should not be generalized for other companies. In this research, there is only micro-environment considered for developing strategies. For further researches, macro environment factors may be embraced with other analyzes such as PEST or PESTEL. Also in the research while Porter's five forces' dependencies are analyzed by DEMATEL technique, SWOT factors are assumed as independent. This issue shall be thought in future researches. 


\section{References}

Agarwal, R., Grassl, W., Pahl, J. (2012). Meta-SWOT: Introducing a New Strategic Planning Tool. Journal of Business Strategy, 33(2): 12-21.

Aksakal, E., Dağdeviren, M. (2010). ANP ve DEMATEL Yöntemleri ile Personel Seçimi Problemine Bütünleşik Bir Yaklaşım, Gazi Üniv. Müh. Mim. Fak. Der. 25(4): 905-913.

Arslan, O., Turan, O. (2009). Analytical Investigation of Marine Casualties at the Strait of Istanbul with SWOT-AHP Method. Maritime Policy \& Management, 36(2): 131-145.

Barboza, J. V. S., Rojo, C. A. (2015). Diagnóstico Estratégico em uma Empresa do Setor Moveleiro por Meio das Análises SWOT, Matriz BCG e 5 Forças de Porter. Revista da Micro e Pequena Empresa FACCAMP, 9(1): 103-116.

Bernroider, E. (2002). Factors in SWOT Analysis Applied to Micro, Small-to-Medium, and Large Software Enterprises: An Austrian Study. European Management Journal, 20(5): 562-573.

Catron, J., Stainback, G. A., Dwivedi, P., Lhotka, J. M. (2013). Bioenergy Development in Kentucky: A SWOT-ANP Analysis. Forest Policy and Economics, 28: 38-43.

Chung, S.H., Lee, A.H.L., Pearn, W.L. (2005). Analytic Network Process (ANP) Approach for Product Mix Planning in Semiconductor Fabricator. International Journal of Production Economics, 96(1): 15-36.

Crawford, G., Williams, C. (1985). The Analysis Of Subjective Judgment Matrices, Project AIR FORCE Report Prepared for the United States Air Force, 1-34.

Dobbs, M. E. (2014). Guidelines for Applying Porter's Five Forces Framework: A Set of Industry Analysis Templates. Competitiveness Review, 24 (1): 32-45.7

Foods That Increase Serotonin Levels in the Brain. http://mentalhealthdaily.com/2015/04/06. Access Date: $09^{\text {th }}$ December 2016.

Görener, A., Toker, K., Uluçay, K. (2012). Application of Combined SWOT and AHP: A Case Study for a Manufacturing Firm. Procedia-Social and Behavioral Sciences, 58: 1525-1534.

Grundy, T. (2006). Rethinking and Reinventing Michael Porter's Five Forces Model. Strategic Change, 15: 213-229.

Güçlü, N. (2003). Strategic Management. Gazi Eğitim Fakültesi Dergisi, 23(2): 61-85.

Ip, Y. K., Koo, L. C. (2004). BSQ Strategic Formulation Framework. Managerial Auiditing Journal, 19(4): 533-543.

Kahraman, C., Demirel, N. Ç., Demirel, T. (2007). Prioritization of E-Government Strategies Using a SWOT-AHP Analysis: The Case of Turkey. European Journal of Information Systems, 16(3): 284-298.

Kajanus, M., Leskinen, P. Kurttila, M., Kangas, J. (2012). Making Use of MCDS Methods in SWOT Analysis - Lessons Learn in Strategic Natural Resources Management. Forest Policy and Economics, 20: 1-9.

Keyes, Ralph. The Quote Verifier. Simon \& Schuster. New York, NY (2006). ISBN 978-0-312-34004-9. 
Kurtilla, M., Pesonen, M., Kangas, J., Kajanus, M. (2000). Utilizing the Analytic Hierarchy Process (AHP) in SWOT Analysis - A Hybrid Method and Its Applications to a Forest-Certification Case. Forest Policy and Economics, 1: 4152.

Lee, S. F., Ko, A. S. O. (2000). Building Balanced Scorecard With SWOT Analysis, and Implementing Sun Tzu's The Art of Business Management Strategies on QFD Methodology", Managerial Auditing Journal, 15(1): 68-76.

Liu, H. C. (2016). Evaluation of the Balance and Variation of DEMATELs by Using Liu's Integrated Validity Index. Journal of Data Science, 14: 383-392.

Naserbakht, M., Asgharizadeh, E., Mohaghar, A., Naserbakht, J. (2008). Merging the Porter's Diamond Model with SWOT Method in Order to Analyze the Iranian Technology Parks Competitiveness Level. PICMET 2008 Proceedings, 27-31 July, Cape Town, South Africa: 276-283.

Porter, M. E. (1979). How Competitive Forces Shape Strategy. Harvard Business Review: 137-145.

Rajasekar, J., Raee, M. A. (2013). An Analysis of the Telecommunication Industry in the Sultanate of Oman Using Michael Porter's Competitive Strategy Model. Competitiveness Review, 23(3): 234-259.

Shahabi, R.S., Basiri, M.H., Kahag, M.R., Zonouzi, S.A. (2014). An ANP-SWOT Approach for Interdependency Analysis and Prioritizing the Iran's Steel Crap Industry Strategies. Resources Policy, 42: 18-26.

Sheykhan, A., Zakeri, S., Hooman, A., Mousavi, M. H. (2014). A Proposed Framework for Selection and Prioritization of the Best Strategies: A Hybrid SWOT Analysis, Fuzzy PROMETHEE II and Porter's Generic Strategies, 6(6): 313-320.

Shrestha, R. K., Alavalapati, J. R. R., Kalmbacher, R. S. (2004). Exploring the Potential for Silvopasture Adoption in South Central Florida: An Application of SWOTAHP Method. Agricultural Systems, 81(3): 185-199.

Supçiller, A. A., Çapraz, O. (2011). AHP-TOPSIS yöntemine dayalı tedarikçi seçimi uygulaması, İstanbul Üniversitesi Iktisat Fakültesi Ekonometri ve İstatistik Dergisi, 13, 1-22.

Supeekit, T., Somboonwiwat, T., Kritchanchai, D. (2016). DEMATEL-Modified ANP to Evaluate Internal Hospital Supply Chain Performance, Computers \& Industrial Engineering, 102: 318-330.

Swaan Arons, H, \& Waalewijn, Ph. (1999). A Knowledge base representing Porter's Five Forces Model. http://hdl.handle.net/1765/753. Access Date: 01 ${ }^{\text {st }}$ December 2016.

Turkey Food and Beverage Industry Associations 2016 Report. http://www.tgdf.org.tr/ Access Date: $17^{\text {th }}$ December 2016.

Wang, X., Liu, Z., Cai, Y. (2015). A Rating Based Fuzzy Analytic Network Process (FANP) Model for Evaluation of Ship Maneuverability. Ocean Engineering, 106: $39-46$.

Wang, Z., Jiang, X., Bian, S., Ma, Y., Fan, B. (2016). Accurate Load Modeling Based on Analytic Hierarchy Process, Journal of Electrical and Computer Engineering: $1-13$. 
Wudhikarn, R., Chatpitak, N., Neubert, G. (2015). Use of an Analytic Network Process and Monte Carlo Analysis in New Product Formula Selection Decisions. AsiaPasific Journal of Operational Research, 32(2): 1-28.

Xingang, Z., Jiaoli, K., Bei, L. (2013). Focus on the Development of Shale Gas in China-Based on SWOT Analysis. Renewable and Sustainable Energy Reviews, 21: 603-613.

Yüksel, İ., Dağdeviren, M. (2007). Using the Analytic Network Process (ANP) in a SWOT Analysis - A Case Study for a Textile Firm, Information Sciences, 177: 3364-3382.

Zhu, L., Hiltunen, E., Antila, E., Huang, F., Song, L. (2015). Investigation of China's Bio-Energy Industry Development Modes Based on a SWOT-PEST Model. International Journal of Sustainable Energy, 34(8): 552-559. 